Canadian University Music Review

Canadian Unlversity Music Review

Revue de musique des universités canadiennes

\title{
Musico-poetic Form in Satie's "Humoristic" Piano Suites (1913-14)
}

\section{Alan M. Gillmor}

Numéro 8, 1987

URI : https://id.erudit.org/iderudit/1014932ar

DOI : https://doi.org/10.7202/1014932ar

Aller au sommaire du numéro

Éditeur(s)

Canadian University Music Society / Société de musique des universités canadiennes

ISSN

0710-0353 (imprimé)

2291-2436 (numérique)

Découvrir la revue

Citer cet article

Gillmor, A. M. (1987). Musico-poetic Form in Satie's "Humoristic" Piano Suites (1913-14). Canadian University Music Review / Revue de musique des universités canadiennes, (8), 1-44. https://doi.org/10.7202/1014932ar

All Rights Reserved (C Canadian University Music Society / Société de musique des universités canadiennes, 1986
Ce document est protégé par la loi sur le droit d'auteur. L'utilisation des services d’Érudit (y compris la reproduction) est assujettie à sa politique d'utilisation que vous pouvez consulter en ligne.

https://apropos.erudit.org/fr/usagers/politique-dutilisation/ 


\title{
MUSICO-POETIC FORM IN SATIE'S \\ "HUMORISTIC" PIANO SUITES (1913-14)
}

\author{
Alan M. Gillmor
}

Erik Satie has become an almost iconic figure in the jagged landscape of contemporary musical aesthetics. His anti-Romantic rejection of the sublime, his glorification of the homely and the commonplace, his highly refined sense of the absurd and the whimsical are the primary qualities that have endeared him to the more iconoclastic members of the critical fraternity. A parody of the bohemian dandy, the strange little man from Normandy emerges as the quintessential modernist.

Stylistic analysis is, of course, fundamental to any critical evaluation of a composer's oeuvre, but with an artist of Satie's strange and fanciful nature there is a strong temptation to substitute anecdote for analytical perception. Consequently the composer's musical achievement has been obscured by a plethora of fascinating documentation concerning his life and times, his literary activities, and his connections with sundry painters, poets, and men and women of the theater. This is an understandable tendency, for like most progressive music composed between 1890 and 1920 Satie's resists traditional analytical methods. Despite its deceptive simplicity his music - as much as Debussy's or Ives' - requires its own analytical framework, one that recognizes the fragile juxtaposition of multiple layers of aesthetic meaning.

It is important to recognize from the outset that Satie was more than simply a musician. The recent publication of his considerable body of 
writings ${ }^{1}$ shows him to be a literary figure of some importance and unquestioned individuality. His whimsical drawings and striking calligraphy have received nearly as much attention. And when these literary and artistic fantasies are married to the musical, as in the extraordinarily Satiean Sports et divertissements of 1914, we have a score that properly belongs as much on the walls of an art gallery as on the shelves of a music library. Satie's is an exceedingly fragile art form, a delicate interweaving of individual strands of artistic experience suspended in exquisite balance, and any attempt to define this elusive art is like trying to dissect the proverbial butterfly. As Lothar Klein has noted: "It is useless to comment on any specific work, for Satie's work eludes musical analysis. One must contemplate the whole oeuvre and the thought behind it; comprehending this, the swerving movements of modern music can be followed more easily" (Klein 1966: 25-26).

The series of whimsical piano suites composed in quick succession between April 1913 and July 1914 are not only among Satie's best known keyboard works, they remain the purest examples of the composer's peculiar genius, revealing in abundance the endearing qualities that have become virtually synonymous with his name: wit, parody, irony, fantasy. The most beguiling and perhaps most controversial Satie mannerism - the droll and often nonsensical commentaries sprinkled liberally throughout the scores - is exploited in the suites of 1913-14 and carried to a new level of imaginative fancy. The short, cryptic

1 The bulk of Satie's published writings appeared originally in a variety of obscure "little reviews" between 1912 and 1924, and although portions of his literary output have been reprinted in a number of publications over the past thirty years, the first complete scholarly edition of Satie's writings (published and unpublished) is that of Volta (1977), the first of a planned three volumes that eventually will include the composer's correspondence and the texts and poems that accompany many of his musical scores.

Although restricted primarily to the published material, Wilkins' (1980a) edition of Satie's writings is of inestimable value to the English reader, bringing together in excellent translations (much of it for the first time) the best of Satie's subtle and idiomatic prose. In addition, Wilkins has published extensive selections from Satie's correspondence; see Wilkins (1975; 1980a; and 1981). 
phrases which began to appear sparingly as early as 1890 in the Gnossiennes where, for example, he instructs the pianist to "think right," "wonder about yourself," play a passage "on the tip of the tongue," or "with amazement," give way to a veritable barrage of bizarre annotations and performance directions. By 1914, beginning with the Heures séculaires et instantanées, the verbal quips are replaced by virtually continuous monologues of a strange, frequently surrealistic nature. The fact that the composer prefaced this work with a "Warning" forbidding the text to be read aloud during performance has fed a certain amount of controversy. Most Satieans are inclined to take the composer at his word in this instance. A notable exception is the American critic Carl Van Vechten, who expressed the opinion as long ago as 1917 that Satie's comments, like the stage directions in a Bernard Shaw play, should be a vital component of the performance, that the audience should be allowed to share in the fun. He went on to suggest that the eccentric Russian-born pianist Vladimir de Pachmann, remembered not only for his sensitive performances of Chopin but also for his controversial habit of talking to his audiences while playing, would have made the ideal Satie interpreter. "Fancy de Pachmann," he wrote, "playing the delicate Airs to make you run from the Cold Pieces, saying at intervals, softly to his auditors ... En y regardent à deux fois ... Se le dire ... A Plat ... Blanc ... Toujours ... Passer ... Pareillement ... Du coin de la main ..." (Van Vechten 1917: 264). ${ }^{2}$ Van Vechten's is, to be sure, decidedly a minority view. Satie's intuition was right on this point. The ideal realization of a piece such as, say, the quintessentially Satiean Sports et divertissements, would be a private performance in intimate surroundings for a small group of connoisseurs gathered around the piano to delight simultaneously in the sounds, the drawings, the poems, and the composer's exquisite calligraphy. The fact that the

2 Such an approach has occasionally been put into practice, generally with unsatisfactory results. A 1970 recording of the Embryons Desséchés in an orchestral version by Friedrich Cerha (Candide CE 31018) has a female voice reciting Satie's running commentary over the music. A more acceptable though still less than ideal solution has been to project slides of a score such as Sports et divertissements onto a large screen to coincide with the performance. 
score of Sports et divertissements was originally published in an oversize (almost seventeen inches square) loose-leaf format in the composer's autograph hand with illustrations by Charles Martin tends to substantiate such a claim.

The 1913-14 piano suites represent the fulfillment of a creative ideal toward which Satie seems to have been moving almost from the beginning. In these whimsical miniatures we find a unique synthesis of elements - music, poetic fantasy, calligraphy - suspended in a delicate equilibrium. Like Connecticut's visionary transcendentalist, Charles Ives, Satie was deeply attached to a particular sonic environment, in his case the breezy satirical world of the cabarets, circuses, and music halls of turn-of-the-century Montmartre. But whereas the American - his idealism rooted in a hard-headed Yankee Puritanism with its overtones of Emersonian individualism and Thoreauvian asceticism incorporated jumbled fragments of his New England soundscape into musical structures of enormous complexity, the Frenchman, ever suspicious of the grandiose and the apocalyptic, placed his commonplace sonic fragments into musical structures of extreme simplicity, wherein each individual strand of experience stands out in bold relief. Nor should it be forgotten that apparitions of popular airs appear in numerous works of Debussy, beginning at least as early as $1880-83$ with his setting of Vincent Hyspa's La Belle au bois dormant, which makes use of "Nous n'irons plus au bois," a children's song also quoted on one occasion by Satie and used again on three later occasions by Debussy: in the third of the 1894 Images for piano - which is virtually a set of variations on the tune - in "Jardins sous la pluie" from the Estampes (1903), and in "Rondes de printemps" from the orchestral Images of 1905-12.

Beginning with the Descriptions automatiques of 1913, Satie sprinkled his scores with tunes indigenous to his soundscape - children's songs, folk songs, airs from once popular operettas, and, occasionally, themes from the "classics." (See Appendix for a complete list of identifiable borrowed material.) Like Debussy in his use of the famous opening motif from the Tristan Prelude in the central section of "Golliwog's Cake-walk," Satie's quotations occasionally have a parodistic intent. Unlike Ives, however, he was not seeking anything nearly so grand as 
"transcendental unity," and neither of the French composers even remotely approached the free-association, "stream-of-consciousness" flow of the American's multi-layed conceptions.

Satie, of course, would not have known of the existence of Ives as early as 1913, and likely not at all; nor does it seem that Debussy's music provided the direct stimulus for the piano suites. ${ }^{3}$ Rather he was simply extending the commonplace practice of the Montmartrian chansonnier in utilizing pre-existing tunes in new - and often satirical - contexts. Most of the songbook collections of the period were printed entirely, or at least partially, without music, with an indication of the tune to be used for a particular chanson. Jules Jouy, for example, one of the Chat Noir regulars during Satie's tenure at the famous cabaret, resorted to a number of the same tunes that later make an appearance in Satie's piano works, among them "Maman, les p'tits bateaux" and "La Carmagnole"; as well, we find numerous airs from the French opera and operetta repertoire - Boïeldieu's La Dame blanche and Planquette's Les Cloches de Corneville, for example (see Jouy 1888). Similarly, Léon Xanrof, in his collections of Chat Noir chansons (see, for exam-

3 It is in fact quite possible that the influence went the other way. One of Debussy's most "Satiean" works is La Boîte à joujoux, a "ballet for children" intended originally for marionettes and completed near the end of 1913. Debussy's charming make-believe world of dancing dolls is a veritable compendium of familiar tunes - children's ditties, folk songs, military tattoos, popular operatic airs - some dozen tunes in all, among them several that found their way into Satie's music the very same year. Like Satie's piano suites, the score of $\mathbf{L a}$ Boitte à joujoux carries a fairly continuous verbal commentary, printed over the appropriate music, outlining the action of the ballet. Moreover, Debussy's quotations bear the same musico-poetic relationship to the drama as Satie's to his fanciful programs, though with less of the latter's ironic detachment and delicious sense of the absurd. Although Debussy had discussed the scenario of the ballet with its author, André Hellé, as early as February 1913, he did not begin work on the score until the beginning of the summer, by which time Satie's Descriptions automatiques - the first of the suites to make liberal use of quoted material - had been completed and even performed at the Conservatoire by Ricardo Viñes. La Boîte à joujoux its orchestration completed by André Caplet, had to wait until December 1919 for its first public performance, although the piano score was published by Durand in 1913. 
ple, Xanrof 1890), appropriated well-known operatic airs, as did Satie's collaborator, Vincent Hyspa, whose "cover" composers included Offenbach and Massenet as well as fellow chansonniers such as Paul Delmet and Georges Tiercy (see Hyspa 1903).

Not unlike the majority of his French contemporaries Satie seemed to have had a strong need for extra-musical stimuli in order to set his musical imagination in motion. And although both Debussy and Ravel occasionally made use of pre-existing material for particular expressive purposes, Satie's "found objects" seem to have been the actual stimuli that sparked a chain of events leading to the finished musico-poetic products.

Vieux sequins et vieilles cuirasses might be taken as a typical case in point. Unfortunately the surviving manuscripts do not point to a clear compositional modus operandi. However, we can speculate that the initial points of departure for these and most of the other piano works of 1913-14 were well-known French songs - children's ditties, political songs, operatic airs - that had a wide currency in France at the time and would have been familiar (as some of them still are) to several generations of French school children. Had Satie wished to locate a readily available printed source for most of the tunes he quotes, he would have had to look no further than the Nouveaux Larousse illustré, 4 the great French encyclopedia which, unlike most of its

4 Nouveaux Larousse illustré: Dictionnaire universel encyclopédique, Claude Augé, ed. (Paris: Libraire Larousse, 1898-1904). The more extensive Grand Dictionnaire universel du XIXe siècle, Pierre Larousse, ed. (Paris, 1866-79) contains many of the same musical entries, but with fewer examples of printed music.

Almost all of the songs Satie quotes in the 1913-14 piano pieces belong to the repertoire of French children's songs. Even such songs as " $L a$ casquette du père Bugeaud," "Le bon roi Dagobert,"and "Malbrough s'en va-t-en guerre," which he borrowed, were firmly entrenched in the repertoire of children's songs by the end of the nineteenth century. Among other printed sources of this material that Satie may have consulted are several collections made in the 1880s by the composer and archivist Jean-Baptiste Weckerlin - see Weckerlin (1884); (1885); (1886); and (1889) - charmingly illustrated 
English-language equivalents, contains numerous entries for individual folk songs, popular airs, and operettas which include, in addition to historical backgrounds to the pieces, the texts as well as, in a good many cases, the printed music.

It is fairly obvious that the musico-poetic stimulus for the "Danse cuirasse" from Vieux sequins et vieilles cuirasses was the song "La casquette du père Bugeaud," a military song that originated among the Zouaves, the companies of nineteenth-century Algerian infantry noted for their colorful uniforms of baggy trousers, open-fronted jackets, and tasseled caps or turbans. In the 1840s, during the French conquest of Algeria, Marshal Thomas-Robert Bugeaud, a veteran of the Napoleonic Wars, led his Zouave troops on a series of bloody campaigns against the Arabs that finally led to the defeat and capture of the Arab chief Abd-el-Kader in 1847 and the consolidation of the French empire in North Africa. According to the legend, the French camp was hit one night by a surprise attack, whereupon Bugeaud rushed from his tent to rally his men and repulse the enemy. When the struggle ended, he noticed that his victorious soldiers were staring at him with tittering amusement. Placing his hand on his head, the embarrassed Marshal discovered that, in the heat of the moment, he had fought the entire action without his large, visored officer's cap, his head adorned instead only by a simple cotton nightcap. "Go, look for my cap!" he cried, whereupon the troops began murmuring the refrain, "Have you seen the cap, the cap, have you seen the cap of father Bugeaud?" to a bugle tune

editions with piano accompaniments by the author. To these we might add a similar collection arranged by the composer/organist Charles-Marie Widor (1883). These collections alone contain every children's song Satie is known to have borrowed.

An immediate precedent for the wholesale quotation of children's songs in a series of piano pieces is $L a$ Nursery, five suites composed by Désiré-Emile Inghelbrecht and published between 1905 and 1911. Considering Inghelbrecht's close association with Debussy and his circle - he conducted the first concert performance of Le Martyre de Saint-Sébastien in 1912 - it is probable that Satie was aware of La Nursery, each of whose thirty pieces is based on a children's song, among them several that later appear in his own piano works. 
known in the French army as "Aux champs (en marchant)." The Marshal was not offended. Several days later, when the word came to break camp, he commanded his bugler "to sound the Casquette!" The troops rode off singing a song that henceforth accompanied the Zouaves into battle and thus entered the annals of regimental folklore:

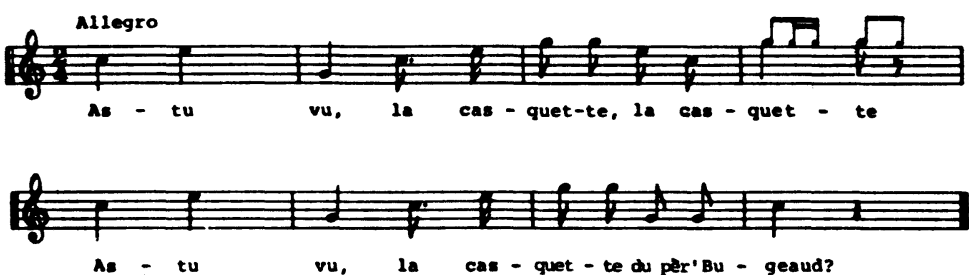

Figure 1. : "La casquette du pére Bugeaud" (from Nouveaux Larousse illustré, II: 544)
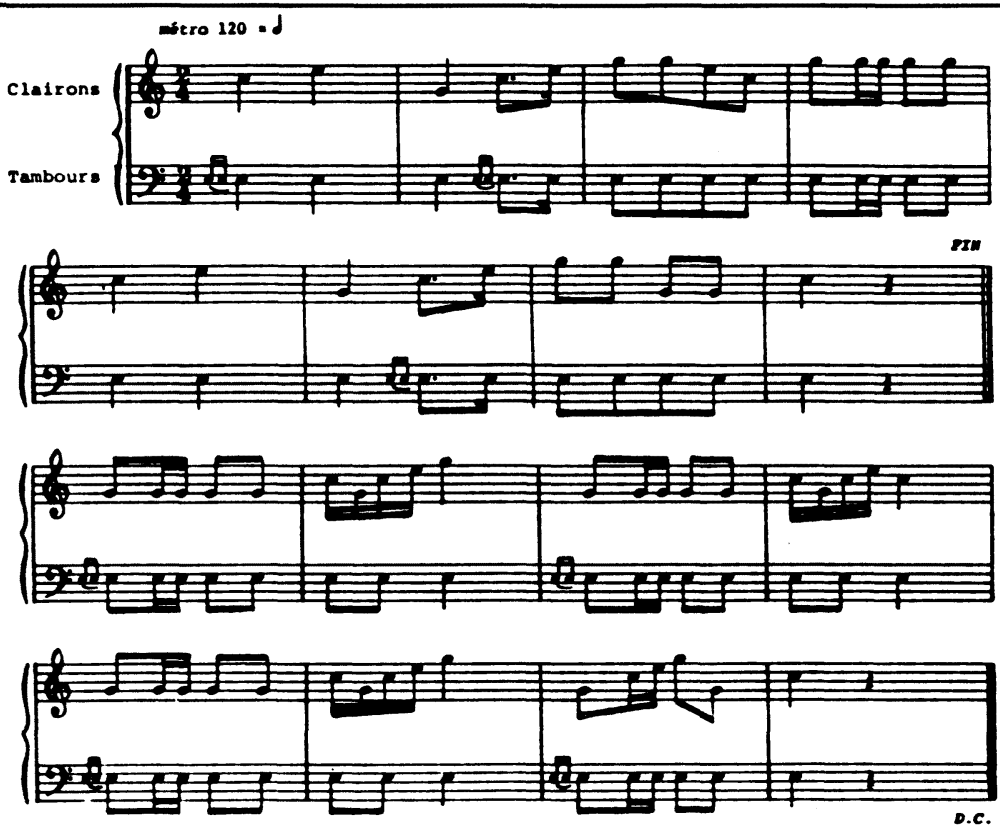

Figure 2. : "Aux champs (en marchant)" (from Instruction $d u$ 18 juin 1912 sur les batteries et sonneries (commune à toutes les armes), p. 80) ${ }^{5}$ 
This is precisely the kind of story that would have delighted Satie. And no doubt the additional fact that the word "zouave" - in obvious reference to the odd uniforms of the Algerian infantry - eventually entered French slang in the sense of "playing the fool" (in dress or manners) would not have escaped him. Although it is likely that Satie, like most Frenchmen of his generation, would have been familiar with "La casquette du père Bugeaud," it is tempting to speculate that he turned to the Nouveaux Larousse illustré for background information on the song as well as for the text and music. We know that he was an inveterate reader, with a special fondness for anything that struck him as strange and exotic. It is in fact possible that it was a random encounter with the encyclopedia that suggested this and other tunes to him in the first place. Had he, then, located the entry for "La casquette du père Bugeaud," he could hardly have failed to notice the adjacent entries under "casque," which in French can refer either to a helmet or to a type of mollusk. Having previously dealt with mollusks in his Embryons desséchés, the composer here seems to have been interested only in the military meaning of the word, and the article on helmets, lavishly illustrated with engravings of historical battle helmets from ancient Assyrian to contemporary colonial French, could only have served to reinforce the chain of associations that resulted in further military symbolism in the last piece of the set and contributed to the formulation of the suite's title.

The "Danse cuirassé"s subtitle ("Période grecque") may be an illusion to the Greek ancestry of its dedicatee, Michel Calvocoressi. The Nouveaux Larousse illustré prints only the opening period of the song, whereas most printed versions include, as an instrumental refrain, the B section of "Aux Champs (en marchant)" as well, which Satie also quotes in the "Danse cuirassé," making slight alterations to measures 2,4 , and 6 of the fanfare.

5 Ministère de la défense, Instruction du 18 juin 1912 sur les batteries et sonneries (commune à toutes les armes) (Paris: Charles Lavauzelle, 1958). 
The first part of the suite's title is a reference to the first piece in the set, "Chez le marchand d'or," subtitled "Venise XIIIe siècle," a sequin being a gold coin first minted in Venice toward the end of the thirteenth century (about 1280) and maintained in use until the fall of the Venetian Republic five centuries later during the Napoleonic period. Here the musical symbolism is fairly obvious. The only identifiable pre-existent tune found in the piece is the "Song of the Golden Calf" from Act II of Gounod's Faust, in which Mephistopheles exhorts Wagner and the other students to worship the mighty Golden Calf, to submit, in other words, to the lure of gold, an obvious reference to the gold merchant's greedy passion for the shiny metal. As Satie's running verbal commentary informs us, he fondles his gold, smothers it in kisses, literally savors it by putting ten thousand gold francs into his mouth at one time, wallows in it, and rolls around in his coffer to the point where he feels stiff and sore all over from his exertion. Early in the piece when the merchant embraces an old sack full of coins Satie slyly introduces the opening motif of Mephistopheles' aria against a slithering chromatic accompaniment:

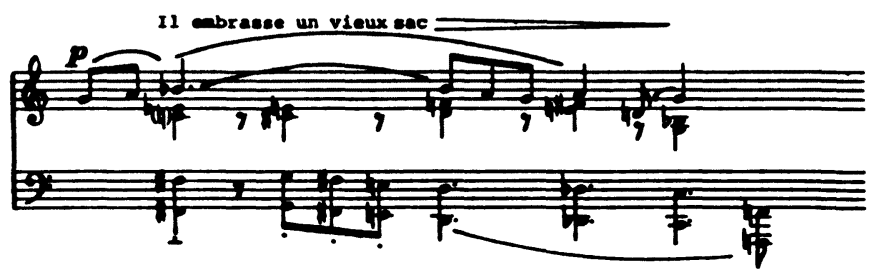

Figure 3. : Satie: "Chez le marchand d'or" from Vieux sequins et vieilles cuirasses (1913) (line 5)

Twice more the phrase is heard, the second time in the bass part over the verbal inscription "He takes a piece of gold and speaks to it in a low voice," a veiled reference, perhaps, to Mephistopheles, one of the great basso roles in all opera. The last entrance of the Mephistophelian motif is accompanied in the score by the words "He is as happy as a king," but like many rich men before and since he is, we can speculate, in clear 
danger of losing his soul, like the ambitious Faust of legend, the great German necromancer who sold his immortal soul to the Prince of Darkness.

In the last piece of the set, "La Défaite des Cimbres," Satie clearly reveals his extra-musical sources in a short note which he had printed in the score. We are asked to imagine a very old man who gives his little grandson a strange course in general history by telling him, each day, stories drawn from his vague memories, heroic tales of ancient battles involving legendary heroes such as the celebrated King Dagobert, the Duke of Marlborough, and the great Roman general Marius. Asleep in his tiny bed, the child has a dream (or rather, as the piece's subtitle informs us, a nightmare) in which he merges these historical figures into one formidable force which sets out to conquer Boïorix, king of the Cimbri, an ancient Teutonic people who invaded Gaul as far north as the Seine, waged war on Celtic tribes in the Danube valley, and penetrated the western borders of Italy until they were defeated in 102 B.C. at Aquae Sextiae (modern Aix-en-Provence) by the Romans under Gaius Marius and ultimately destroyed, along with their king, by the same forces the following year at a great battle on the Raudine Plain near Vercellae (modern Vercelli) in Piedmont, midway between Turin and Milan. As a result of this great victory over the barbarians, Marius was elected consul and hailed throughout the land as the "savior of the country."

6 These are the historical facts. In his note to the score, however, Satie has the dreaming child, his head a jumble of historical facts, confuse time and geography by placing the defeat of the Cimbri at Mons-en-Puelle (now Mons-en-Pévèle), in reality a village in northern France near the Belgian border where, in 1304, the French under Philip the Fair recorded a decisive victory over the Flemings. This surrealistic transmogrification of history mirrors the actual process of subconscious dream activity wherein time becomes suspended in a phantasmagoria of shifting memory fragments. Here we can speculate that the memory of Mons-en-Puelle was triggered by the dreamer's awareness of the fact that Marlborough's 1709 victory at Malplaquet took place not far to the east, about ten miles south of the Belgian city of Mons. 
Once again we can speculate that this surrealistic fantasy was the offspring of two famous songs - "Le bon roi Dagobert" and "Malbrough s'en va-t-en guerre." And as before, Satie would not have had to go any further than the Nouveaux Larousse illustré to find both words and music as well as relevant historical background. Had he, in fact, troubled to look up "Cimbres" in the encyclopedia he could hardly have failed to notice the succeeding entry, "Cimbres, La Défaite des," the title of an 1833 painting by Alexandre-Gabriel Decamps, an artist noted particularly for his historical and religious subjects. Whether he learned of the painting in this fashion or had actually seen the work in the Louvre, which acquired it in 1903, it seems reasonably safe to assume that Satie borrowed the title of this somber painting commemorating the Roman victory at Aquae Sextiae, considered to be Decamp's masterpiece (see Plate I). There is, moreover, strong circumstantial evidence that Satie knew the collections of children's songs by Weckerlin and Widor (see note 4), evidence suggested by Louis-Maurice Boutet de Monvel's whimsical illustrations for "Le bon roi Dagobert" (see Plate II), which may account for the phrase "Pluie des javelots" in line 3 of the score (as well as "Les danseurs reçoivent chacun un coup de sabre qui leur fend la tête" in the last line of the previous piece), hostile acts mentioned nowhere in the song text.

"Le bon roi Dagobert" is a song of unknown provenance that became very popular after 1814 when its satirical couplets were directed at Napoleon and the disastrous Russian campaign. Suppressed by the authorities at the time, it gained a new level of popularity as a proroyalist song after Waterloo and the restoration of the hereditary Bourbon monarchy.

Its hero is Dagobert I (ca.602-39), a Merovingian king of the Franks, who is remembered not only for the magnificance of his court and for his personal love of comfort and luxury - he had in his short lifetime five wives and numerous concubines and ruled over his domains from a solid gold throne forged for him by his treasurer and trusted advisor, the goldsmith Saint Eloi - but also for his patronage of the arts and his protection of the Church, whose glory he celebrated by covering the land with religious monuments, among them numerous monasteries and 


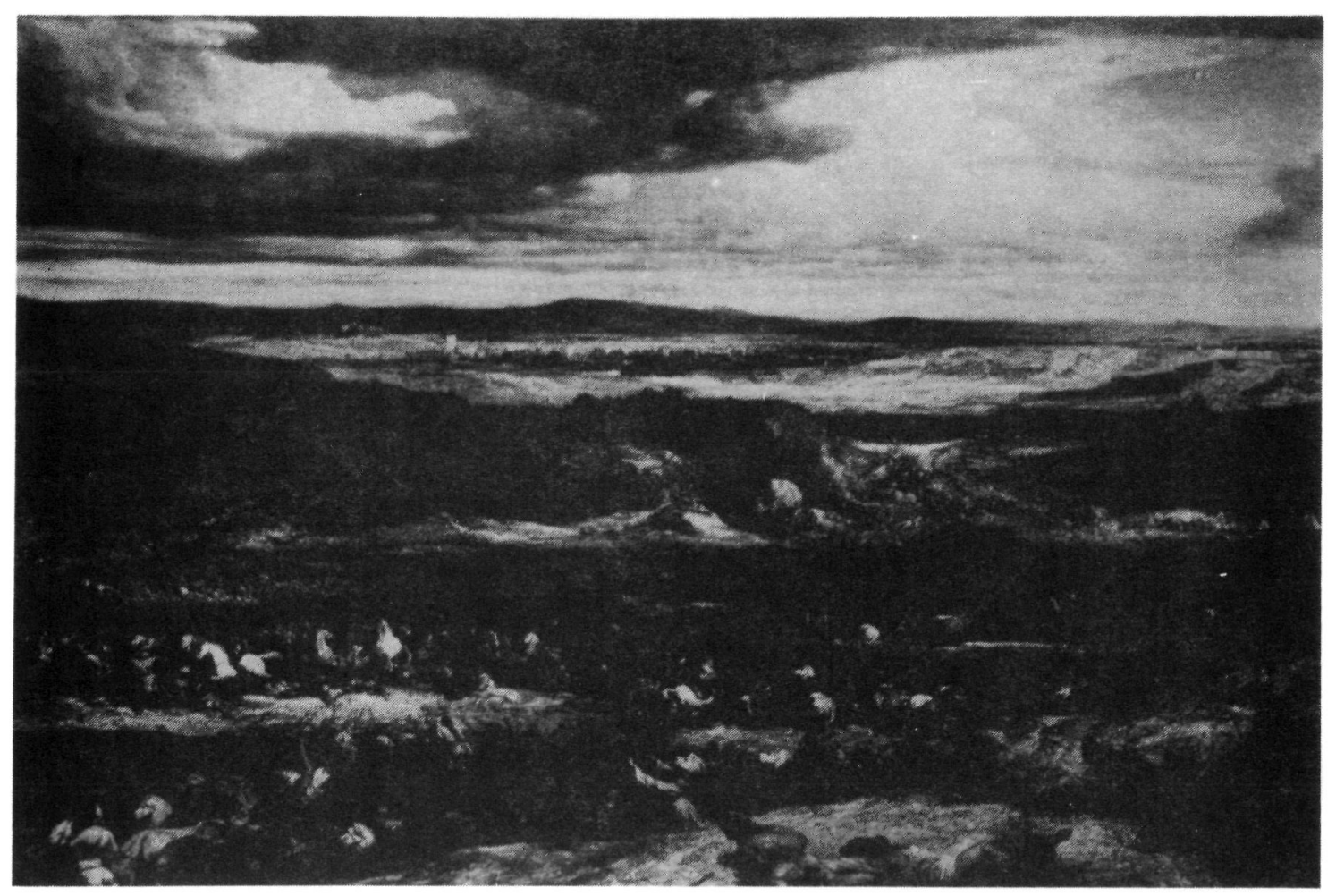

PLATE I

Alexandre-Gabriel Decamps: La Défaite des Cimbres (1833) [from Pierre Miquel, Le Paysage français au XIXe siècle, 1824-1874: L'École de la nature, Vol. 2. (Maurs-la-Jolie: Éditions de la Martinelles, 1975), p. 169] 


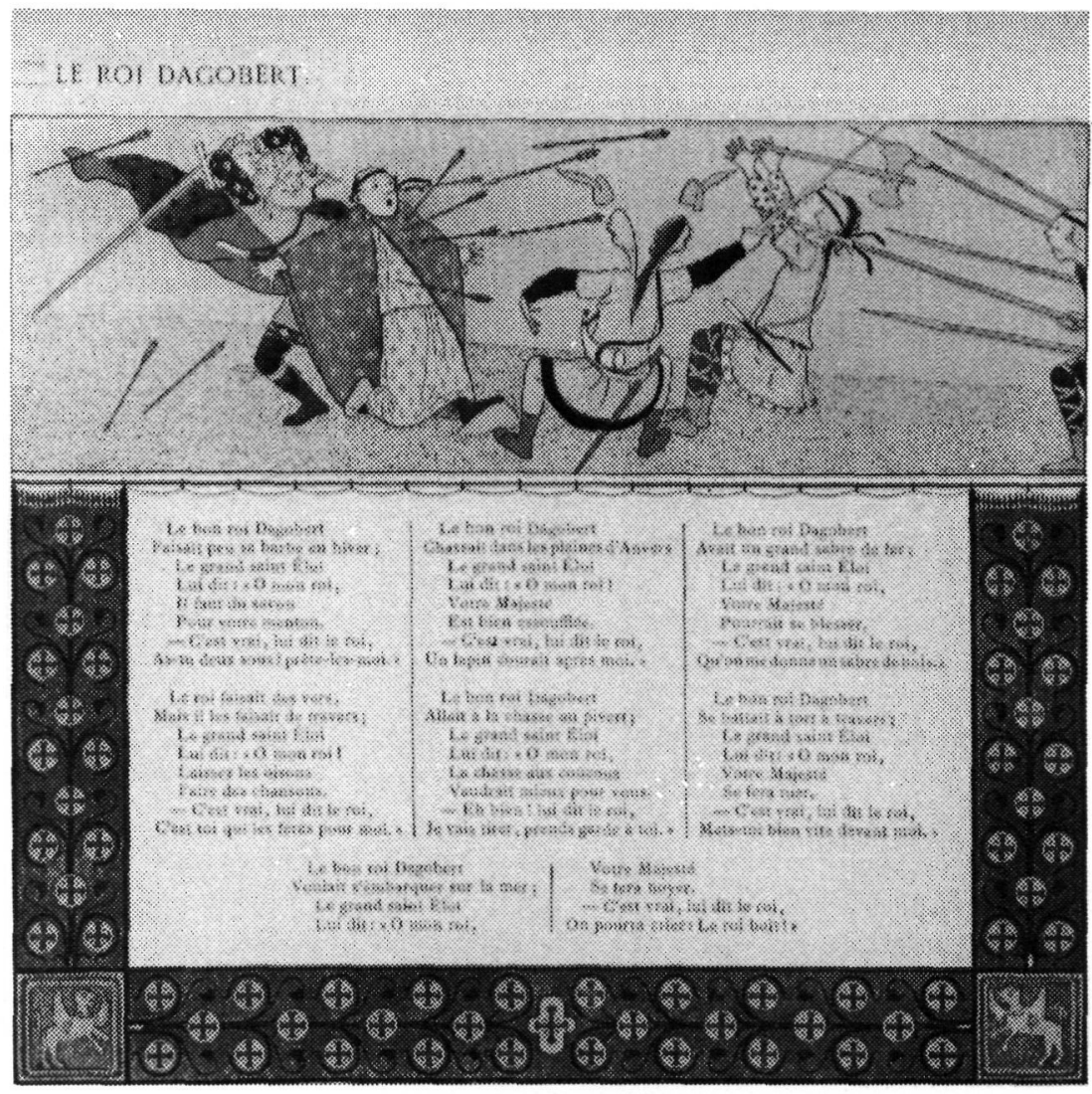

PLATE II

"Le bon roi Dagobert," chromolithograph by

Louis-Maurice Boutet de Monvel, in Jean-Baptiste Weckerlin, Chansons de France pour les petits Français (Paris: Plon-Nourrit, 1884), p. 23 
the basilica of Saint-Denis, where he was interred in a splendidly ornate tomb.

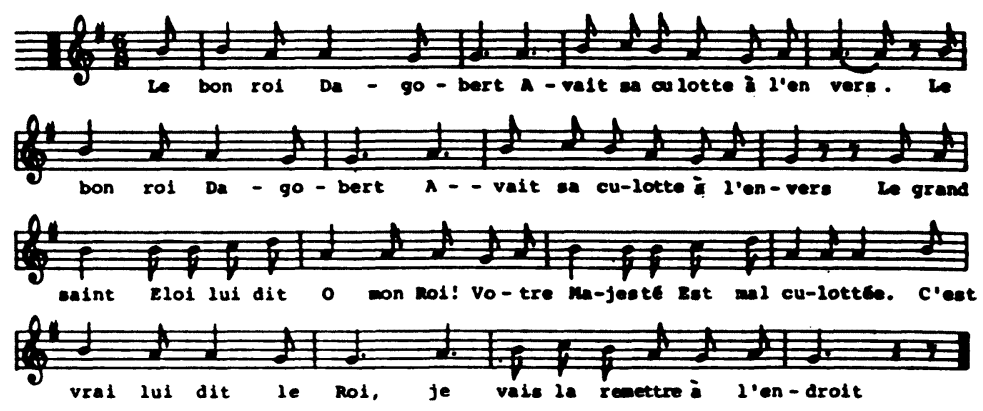

Figure 4. : "Le bon roi Dagobert" from Nouveaux Larousse illustré, III: 490

The subject of "Malbrough s'en va-t-en guerre" is John Churchill, first Duke of Marlborough, who distinguished himself during the War of the Spanish Succession (1701-14) as commander-in-chief of the combined armies of England and Holland with a brilliant series of victories over the armies of Louis XIV - Blenheim (1704), Ramillies (1706), Oudenaarde (1708), culminating in the battle of Malplaquet in September 1709. It is thought that the song dates from the time of Churchill's death in 1722, although there is an alternate theory that it came into existence thirteen years previously during the battle of Malplaquet when rumor swept the French lines that the English general had been killed. In any event it did not come into widespread popularity until the late eighteenth century (after 1781) when it reappeared in the form of a children's ditty, allegedly introduced to the court of Louis XVI and Marie-Antoinette by one Mme Poitrine, a nurse to the royal children. In the English-speaking world it is universally known as "For He's a Jolly Good Fellow": 


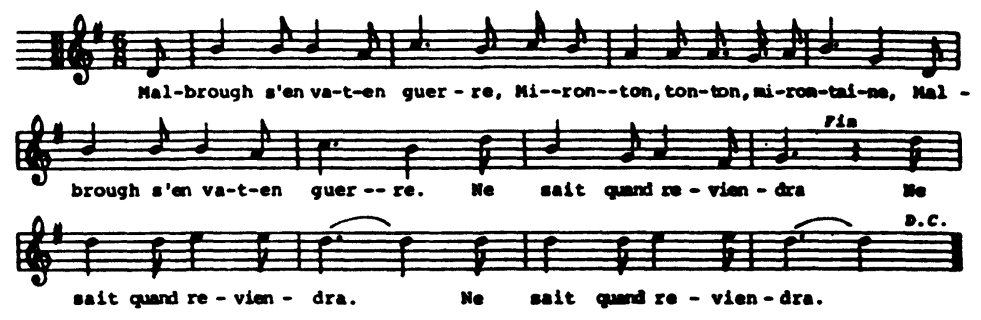

Figure 5. : "Malbrough s'en va-t-en guerre" (from Nouveaux Larousse illustré, V: 868)

Common to both tunes is the bouncing iambic meter which Satie explored at the very beginning of "La Défaite des Cimbres" with the incipit of "Le bon roi Dagobert" sounding in the bass. The opening motif of "Malbrough s'en va-t-en guerre" makes its first appearance as a "Portrait of Marius," and shortly thereafter the first two phrases of the song are sounded in the bass over triplet figurations in the right hand. Characteristically the tune fragments are heard each time on a different tonal level - C, B-flat, G - and occasionally the motifs undergo a process of distortion through small intervallic alterations which serves to reinforce the surrealistic nature of Satie's historical dreamscape.

"Boïorix, king of the Cimbri," is introduced with the last phrase of "Le bon roi Dagobert" - which is identical to the first phrase save for the tonic ending. In line 11 of the piece Satie introduces a phrase of ascending triplets with the verbal inscription "Les Dragons de Villars," a reference to Aimé Maillart's operetta of that name whose most famous aria, "Ne parle pas, Rose, je t'en supplie," had figured in the first of his Chapitres tournés en tous sens, which he had completed just a few weeks previous to the composition of Vieux sequins et vieilles cuirasses. Here, however, there is no obvious musical connection with the operetta. The ghostly regiment of dragoons fleetingly passes through Satie's martial dreamscape, very softly, with a sweeping chro- 
matic flourish in the bass dissonantly harmonized with conspicuous tritones and jarring major and minor seconds.

The final cryptic reference to "Le Sacre de Charles X (267bis)," which is accompanied by one last grandiose statement of the opening phrase of "Le bon roi Dagobert," can only be assumed to be a veiled reference to the reactionary, ultra-royalist Comte d'Artois, crowned King of France as Charles $\mathrm{X}$ in 1825 - an association that may have been suggested to the composer by "Le bon roi Dagobert," considering its historical connection with the Bourbon restoration. In any event, the musical reference to the dissolute and by most accounts intellectually rather undernourished monarch takes on a deliciously satirical overtone in the context of the song's opening verse:

The good king Dagobert

Had his pants on inside out,

The great Saint Eloi

Said to him: O my king,

Your majesty

Is badly trousered.

It's true, replied the king,

I'm going to put them on again right side out.

The satire is all the more pointed when we realize - as Satie quite probably did - that among the more extraordinary pieces of legislation passed by Charles' repressive government was a law making sacrilege a capital crime, a drastic measure to be sure but not a particularly unusual course of action for this last Bourbon king of France who, genuinely believing in the divine right of kings, could only view the Revolution as the work of the Devil. As for the parenthetical "267bis," whether it is a Vexations-like instruction inviting a marathon repetition of the final phrase or an arcane bit of Satiean numerology is anyone's guess! 
Other pieces of the period reveal a similar compositional process. For example, in the little seascape "Sur un vaisseau" from the Descriptions automatiques Satie has the ship snigger (line 8) to the opening phrase of the children's song "Maman, les p'tits bateaux qui vont sur l'eau ont-ils des jambes?" The second piece of the set, "Sur une lanterne," is based on "La Carmagnole," a revolutionary song of unknown authorship which became enormously popular during the Terror as a traditional accompaniment to revolutionary activities, particularly executions. Satie's title, however, is quite probably a reference to an even more famous revolutionary song, "Ca ira!," whose refrain during the Terror became a rallying cry of the lynch mobs: "Ah! ça ira, ça ira, ça ira! Les aristocrates à la lanterne." The carmagnole was a short coat of northern Italian origin introduced into France by immigrant Italian workmen from the district of Carmagnola in Piedmont. Along with black woolen trousers, a scarlet or tricoloured vest, and a red hat it became a kind of official uniform of the insurgents after 1792, and about the same time the name was transferred to a round dance. So famous did the song become that French soldiers of the First Republic became known abroad as "les carmagnoles." The Madame Veto introduced in the first verse of the song is Marie-Antoinette, the haughty queen whose threat to slaughter the entire populace of Paris was neutralized by the revolutionary cannons: 


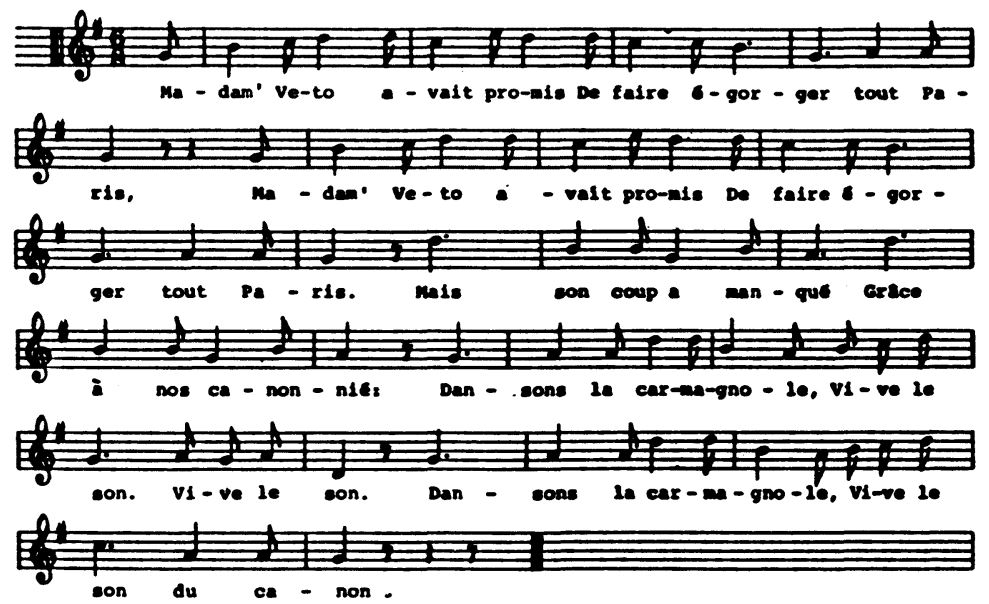

Figure 6. : "La Carmagnole" (from Nouveaux Larousse illustré, II: 509)

Satie borrowed only the opening phrase of the refrain, "Dansons la carmagnole." It is heard seven times in all, twice (in lines 3 and 13) in a slightly altered form. Each statement is heard on a different tonal level - C, G, A, B, D, B-flat - ending on the dominant G, which, however, in the context is heard as a tonic, only to be negated by the closing dissonant ninth chord.

"Sur un casque" has the piano imitating military drum tattoos and bugle calls. Its most overtly comic touch is its final cadence, a loud ostinato passage marked "Heavy as a sow" followed by an even louder (fortissimo) chord with heavy octaves in the bass, which Satie describes as "Light as an egg."

The titles of the Embryons desséchés - a work described in the manuscript by the composer as "absolutely incomprehensible, even to me" - suggests either a random encounter with an encyclopedia or a careful 
reading of Jules Verne, who indulged in such esoteric terminology in his detailed descriptions of marine life in Twenty Thousand Leagues Under the Sea (1870), a book that very likely numbered Satie among its millions of readers.

It is interesting to compare Webster's definition of "holothuria" - "a Linnaean genus containing various rather wormlike aquatic animals ... originally thought to be modified mollusks" - with Satie's fanciful lession in ichthyology:

Ignorant people call it the "sea cucumber." The HOLOTHURIA usually clambers about on stones or rocks. Like a cat, this sea animal purrs; moreover, it spins a kind of moist silk. The action of the light seems to bother it. I once observed a Holothuria in the bay of Saint-Malo.

The only borrowed tune in this piece is "Mon rocher de Saint-Malo," a song composed by Loïsa Puget to words by her husband Gustave Lemoine. Puget's many songs, most of which date from the 1830s and 1840 s, enjoyed an enormous vogue in their day, some of them-such as "Mon rocher de Saint-Malo"-retaining their popularity into the early years of this century. Appropriately, Satie quotes the song's opening phrase-"More than anything else I prefer my mother's home, my rock of Saint-Malo" - at "What a nice rock!" (lines 4-5) and at "It was a very nice rock! very sticky!"(line 17). "Holothuria" and its companion piece "Podolphthalma" are perhaps the most overtly comical pieces Satie ever wrote largely on account of their wildly parodistic final cadences. After the fluid and delicate two-part texture of these pieces, the sudden loud intrusion of obsessively repeated full-voice tonic chords ("Holothuria") or pompous, dramatically spaced tonic/dominant/tonic chords ("Podolphthalma") is quite hilarious. Here Satie's target would appear to be the inflated closing perorations common to many works of the Romantic period - the closing pages of Beethoven's Fifth Symphony, for example, the experience of which is forever altered in the light of Satie's joke. "Holothuria," moreover, has the distinction of containing Satie's most celebrated verbal quip, "Like a nightingale with a toothache" (line 10), a phrase that takes on an 
ironical twist when considered in the context of the previous phrase, "Life is so pleasant" (line 7).

Edriophthalma, the composer correctly informs us in the note to the second piece, are "crustaceans with sessile eyes, that is to say without stalks and immobile." But Satie brings us a deeper insight into the personality of these tiny marine animals by further noting that they are "by nature of a very sad disposition" and prefer "to live in retirement from the world, in holes pierced in the cliffs." Musically, "Edriophthalma"is a parody of the third movement of Chopin's B-flat minor Piano Sonata, perhaps the most famous funeral march in all musical literature. This solemn threnody is suggested very near the beginning of the piece in the dotted rhythm and descending tetrachord that accompanies the phrase "How sad it is!" (line 1). Further insinuations of the theme follow, until the lyrical D-flat major trio theme of the Chopin (here transposed to $C$ major) sings out as "Everyone is reduced to tears" (line 4). Characteristically, the parody operates on several levels simultaneously. The famous Chopin theme is identified in the score as "the celebrated mazurka of SCHUBERT," a doubly curious statement considering that Schubert wrote no mazurkas, celebrated or otherwise, and that, despite Chopin's indelible association with the Polish dance form, the passage in question bears not the slightest resemblance to the unmistakable mazurka rhythm. Satie also tampers with the melody of the original, allowing it to drop to the dominant $G$, thereby eliminating the expressive-and very Chopinesque-rising seventh in the second measure. The original is further deflated through the substitution of a banal Alberti bass for Chopin's elegantly spaced arpeggios: 


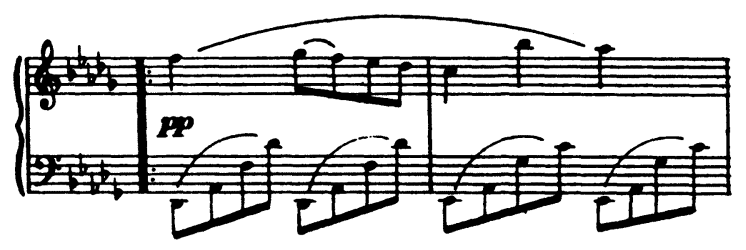

Figure 7. : Chopin: Sonata No. 2 in B-flat Minor for Piano, Op. 35 (1839) III. Marche funèbre, mm. 31-32

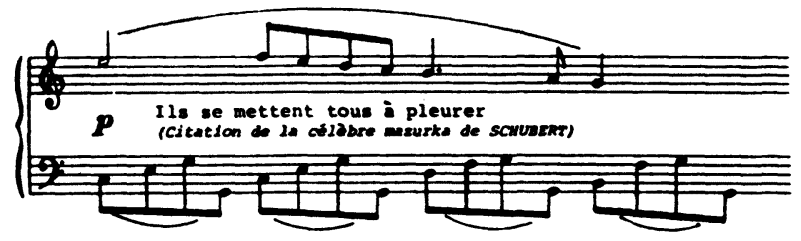

Figure 8. : Satie: "d'Edriophthalma" from Embryons desséchés: (1913) (line 4)

Finally we are introduced to the stalk-eyed crustaceans, the podolphthalma, "skillful and tireless hunters," the composer informs us, "found in every sea." Since these creatures are "very tasty and good to eat" we set off to hunt them. Here the musico-poetic symbolism is rather obscure. The first reference (beginning in lines 5 and 6) is to "The Orangutan Song" from Act III of Edmond Audran's once enormously popular La Mascotte (1880), an operatic farrago of such endearing silliness as to appeal to Satie's highly refined sense of the absurd.

The operetta is set in fifteenth-century Italy during the reign of Lorenzo XVII, an impoverished Prince of Piombino. Learning of Bettina - the 
"mascot" - a beautiful farm girl who apparently brings good luck to her fortunate owner so long as she remains a virgin, Lorenzo proceeds to confiscate her from Rocco, a poor farmer who has just received her as a gift from his wealthy brother Antonio. Exercising his royal prerogative, Lorenzo offers Rocco in return the choice of a dungeon cell or a place in the palace as Lord Chamberlain, which latter situation, not surprisingly, he accepts. Unknown to Lorenzo, Bettina is in love with Pippo, a shepherd.

In the second act preparations are underway at the palace for the wedding of Lorenzo's daughter Fiametta to Fritellini, Prince of Pisa. Pippo arrives at the palace disguised as a dancer and secretly makes arrangements to fly with his willing Bettina, who has now been elevated to the rank of countess. Unfortunately the pair are discovered and sentenced to be hanged. Now we learn that the Princess Fiametta is also in love with Pippo, who, it seems, has been convinced by Lorenzo and Fritellini that Bettina has been unfaithful to him. Stimulated by revenge, Pippo falls easy prey to the seductive Fiametta. Their embrace is interrupted by Lorenzo who, far from being angry, sees a marriage between his daughter and the shepherd Pippo as a sure way to protect the virtue of his mascot, Bettina. Accordingly, Pippo is created Duke of Villa Rosa on the spot and offered a pension of 50,000 crowns a year from the empty treasury of the destitute monarch. Learning of these developments, Bettina consents to marry Lorenzo, who intends it as a matter of form only, for the further protection of his mascot. The plans for the celebration of two royal weddings are disrupted when Bettina and Pippo decide once again to escape together, whereupon they leap from the castle window into the moat below and hence to freedom.

Act III opens in the neighboring Duchy of Pisa, whose Prince Fritellini is at war with Lorenzo. Beaten repeatedly in battle, the ill-fated Lorenzo is dethroned by his angry people and forced to flee with his daughter. Meanwhile Pippo and Bettina (now disguised as a man) reappear as soldiers in Fritellini's victorious army. With his talismanic mascot by his side, Pippo excels in battle and soon rises to the rank of captain. As a reward for his valiant services to the Prince he receives permission to marry his orderly, now revealed as his beloved Bettina. At this point Lorenzo, Fiametta, and Rocco appear at Fritellini's court 
in the disguise of wandering minstrels. Urged on by the soldiers, Fiametta is cajoled into singing "The Orangutan Song," a new chanson, we learn, whose satirical couplets lampoon none other than Fiametta's father, the deposed Lorenzo. Having no choice in the matter, and much to the chagrin of Lorenzo and Rocco, Fiametta launches into a song about a diabolical ape who once ruled Piombino. Seized by a sudden fit of colic, the ape raced off to the woods where he routinely terrified pairs of young lovers, and, it seems, may have violated the young maid Zerlina. But the refrain assures us to tremble not, for they will capture him again. Separated from the operetta-with which it has really nothing much to do anyway! - "The Orangutan Song" became a great parlor favorite during the last decades of the last century:
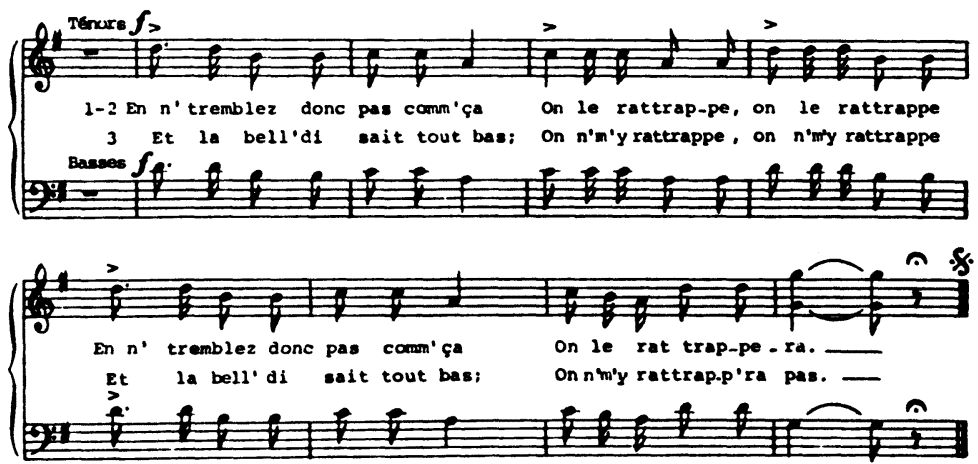

Figure 9. : Audran: "Chanson de l'Orang-Outang" from $\mathbf{L a}$ Mascotte (1880), Act III (Refrain)

In the end youth and love triumph - as of course they always do in the world of operetta. Through her marriage to Pippo, Bettina automatically loses her power as a mascot. Happily, however, the charm 
will be transmitted to their progeny; hence all that is needed is a little time and a little patience.

This boisterous nonsense abounds in the kinds of zany non sequiturs, comic-book characters, and dramatic anarchy we recognize from Satie's own writing. In the context of such effervescent comedy, so dear to the composer's heart, his little drama Le Piège de Méduse, written in the same year as the Embryons desséchés, loses some-though not all-of its startling originality as a kind of Jarry-like prefiguration of Dada and the theater of the absurd.

Returning to "Podolphthalma," we can only surmise that Satie's intention was to advise us against trembling in the face of the fearsome stalk-eyed crustaceans. Perhaps, he suggests, the little creatures can be charmed into submission by a little shepherd girl, whose lovely pastoral melody ("Il était un' bergère") sounds in a clear, diatonic two-part texture before "the adviser" returns with his admonition to tremble not.

Croquis et agaceries d'un gros bonhomme en bois is unique in that its musical references are all derived from "classical" instrumental music, albeit pieces with an obvious programmatic element. The first piece, "Tyrolienne turque," is a kind of Satiean homage to the Tirol and its most famous musical son. The piece is a clear-cut ternary form. Although the outer sections have not been traced to pre-existing music, the tune that emerges at "Rather hot" (lines 3 and 4) has all the characteristics of a tyrolienne or yodeling song. The middle section-beginning at "Very Turkish" (line 6) - is based on a fairly well disguised allusion to the third strain of Mozart's famous "Rondo alla turca" from the A major Piano Sonata, K. 331. Not only is the melody "stretched" out of shape by the repetition of certain notes, with the effect of changing the implied meter from duple to triple, it is undermined by dissonant chords which tend to pull it, as it were, out of harmonic focus.

The "Danse maigre" does not appear to be based on borrowed material, although its title may have been intended as a pun on Cyril Scott's Danse nère (1908), a once extremely popular trifle which Satie may have first encountered through his friend the great Spanish pianist 
Ricardo Viñes, who was known to have included a number of Scott's works in his remarkably heterogeneous programs of contemporary music. Moreover, the "Danse maigre"s subtitle, "à la manière de ces messieurs," would imply an awareness of Ravel's two pastiches $A$ la manière de ... Borodin and Chabrier, which appeared that same year, 1913.

The very title of the third piece, "Españaña," with its added syllable, suggests a parody of Chabrier's famous orchestral fantasia of 1883 . The musical connection with España is revealed at the outset in the ostinato repetition of the rhythmic figure $\int \mathcal{d}$ which figures so prominently in the orchestral work:

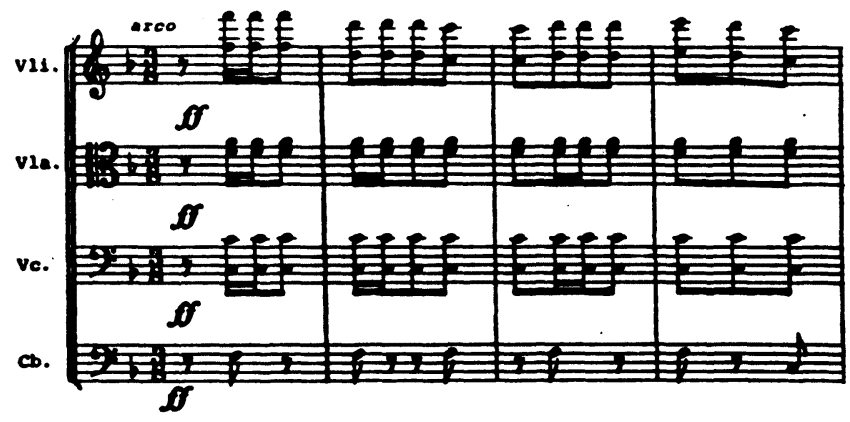

Figure 10. : Chabrier: España (1883) (mm. 61-64)

Twice in "Españaña" Satie quotes the first two measures of Chabrier's motif exactly, once at "Plaza Clichy" (line 11) with dissonant bitonal harmonization, the second time at "Rue de Madrid" (line 13) with "normal" harmonization-a sly dig, perhaps, at the venerable Paris Conservatoire which, in early 1911, moved into new quarters at No. 14, rue de Madrid: 

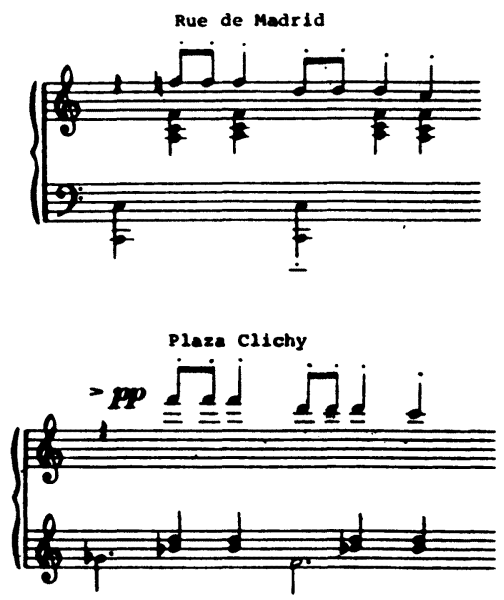

Figure 11. : Satie: "Españaña" from Croquis et agaceries d'un gros bonhomme en bois (1913) (lines 11 and 13)

The other obvious points of correspondence with the Chabrier pieces are the direct quotation (lines 9 and 10) of the big trombone tune that first appears at measures 218-26 of España and the final cadence which, unlike Satie's more usual indeterminate closing gestures, repeats the decisive authentic cadence of the original, even at the same pitch level.

Chapitres tournés en tous sens is aptly titled, considering that its three pieces-more so than is usually the case-have not the slightest programmatic (or musical) connection with one another. In turn we are introduced to a woman whose incessant, inane chatter exhausts her poor husband to the point of death, a man whose sole occupation seems to be humping very large (pumice) stones, much to the amazement of small children, and two prisoners, Jonah and Latude, who dream only of escape from their oppressive confinement. 
In "Celle qui parle trop," the loquacious wife is represented by a rapid triplet patter that purrs along seamlessly in a (tonally) rather aimless fashion, mercifully stopping just short of the final cadence. The longsuffering husband shows his impatience at the very beginning with a few feeble dissonant interjections until, with a rapidly reiterated A (line 12), she commands him to listen to her. She proceeds to jabber aimlessly about mahogany hats, umbrellas made of bone, Mrs. Whats-her-name's marriage to a man as dry as a cuckoo, and the concierge's health. All the while, his isolation symbolized by a theme sounding in $\mathrm{G}$ major two octaves above the motorized triplets, the poor husband gives out the first phrase of the Romance, "Ne parle pas, Rose, je t'en supplie!" from Act I of Aimé Maillart's 1856 operetta Les Dragons de Villars:

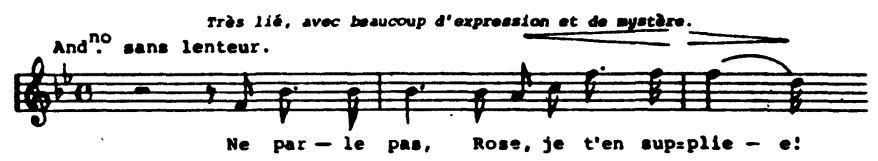

Figure 12. : Maillart: "Ne parle pas, Rose, je t'en supplie!" from Les Dragons de Villars (1856), Act I (mm. 1-3)

But to no avail. The chatter grows louder and the husband, in yet another weary attempt to be heard, sounds his theme (now in $\mathrm{C}$ major) in octaves in the bass (lines 6 and 7). Again his theme is heard (line 10), this time in a slightly distorted shape, only to be cut short by yet another insistent "Listen to me now!" Yet again, now back in G major two octaves removed from the triplet figurations, the theme sounds, slowing very slightly at the end of the phrase. Suddenly the chattering triplets cease. Very slowly and very softly the husband's theme, dissonantly harmonized and chromatically distorted, sounds one last time. Utterly exhausted, he expires on an indeterminate chord, his theme fading on a forlorn minor third: 
Le marl se meurt d'epulsement

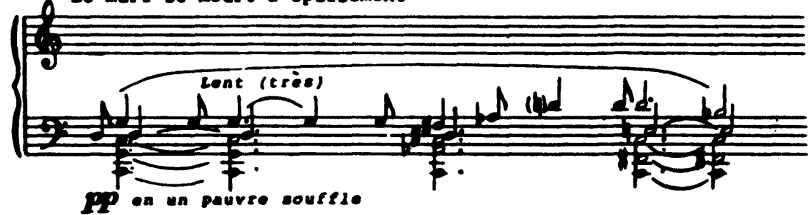

Figure 13. : Satie: "Celle qui parle trop" from Chapitres tournés en tous sens (1913) (line 14)

"Le Porteur de grosses pierres" is based upon an ironic use of the Finale of Act I of Robert Planquette's operetta Rip, an amusing adaptation of a popular French stage version of Washington Irving's legendary tale of Rip Van Winkle, the man who slept for twenty years. One of the operetta's hit tunes was Rip's first-act air with choral refrain, "C'est un rien, un souffle, un rien," which brings down the curtain on Act I:

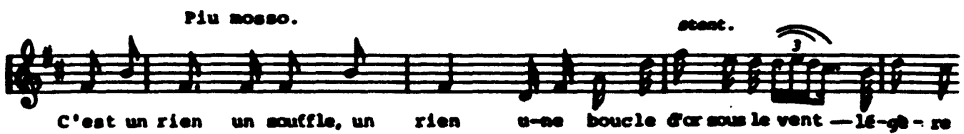

Figure 14. : Planquette: “C'est un rien, un souffle, un rien" from Rip (1884), Act I (Refrain)

Satie quotes this phrase at the outset ("With a great deal of pain") changing only the little cadential melisma of the original to a more predictable arpeggiated figure. It is heard again - transposed from Bflat major to F major - at "In dragging his legs" (line 4), and one last time near the end (in G major) at "He feels the stone slipping from him: it's going to fall" (line 8)-and, with a crunching dissonance-which could be analyzed as superimposed augmented triads on D and E or, 
more accurately, as a whole-tone cluster spanning the augmented sixth D-B-sharp-"There it goes: it falls."

Finally we are introduced to Jonah and Latude in "Regrets des enfermés," the old Testament prophet who displeased God and the eighteenth-century French adventurer who displeased Louis XV - which amounts to the same thing. For thirty-five years Jean-Henri Masers de Latude was imprisoned in the Bastille and elsewhere for concocting a clumsy plot designed to ingratiate himself to Mme de Pompadour, the mistress of Louis XV. Secretly he sent her a box rigged to explode upon opening, and then arranged to inform her of a plot against her life before the fatal moment should arrive. Alas, the ruse was discovered. The royal mistress was not amused, and on 1 May 1749 the unfortunate Latude was incarcerated. Despite three attempts at escape he remained in custody until 1784. After the Revolution he was rehabilitated and awarded an indemnity from the heirs of Mme de Pompadour. He died in Paris on the first day of the year 1805, leaving behind a long account of his imprisonment which, some thirty years later, became the basis of a popular play co-authored by René-Charles Guilbert de Pixerécourt - "the Corneille of the Boulevards" - and Anicet Bourgeois.

Jonah and Latude, Satie informs us, though separated by many centuries, are seated in the shade, thinking. "I am the sailors' Latude," says Jonah, to which Latude replies: "I am the French Jonah." They seem to catch glimpses of the good old sun, and they dream only of escape-one from the dark seclusion of a whale's belly, the other from the musty confines of a royal dungeon - all of this to repeated statements of the initial phrase of "Nous n'irons plus au bois," a famous children's round dance used previously by several French composers of the period, notably Debussy. 

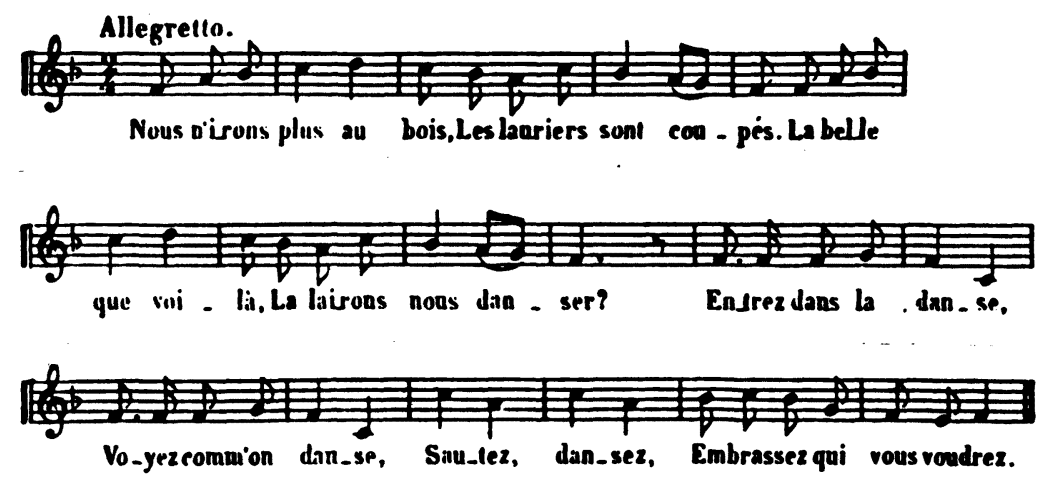

Figure 15. : "Nous n'irons plus au bois"

Satie hints at the song at the outset in an ostinato figure based on the tune's first four notes, oddly harmonized with augmented fourths. In lines 3 and 4 we hear the entire opening phrase (with small adjustments to measures 2 and 3 of the melody) in the minor mode, followed immediately by a repetition of the four-note ostinato figure, transposed from $\mathrm{C}$ major to $\mathrm{G}$ major and now harmonized with perfect fourths. The remainder of the piece consists mainly of repetitions of the tune's opening phrase in varying dissonant and bitonal harmonizations and at varying tonal levels ( $\mathrm{C}$ major, line 6; $\mathrm{F}$ major, line 8; $\mathrm{D}$ minor veering to $C$ major, line 9; E-flat major, lines 12 and 13; $G$ major, lines 16 and 17), interspersed with variants of the four-note motif. A particularly interesting statement (lines 12 and 13) contrapuntally combines the opening phrase (right hand) with a variant of the four-note motif (left hand): 


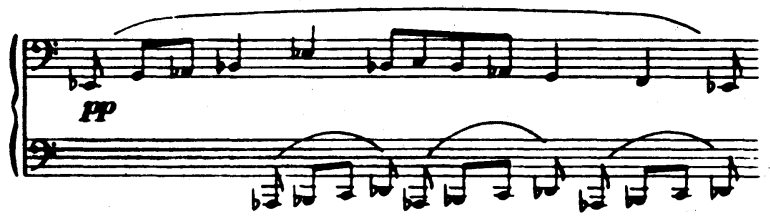

Figure 16. : Satie: "Regrets des enfermés" from Chapitres tournés en tous sens (1913) (lines 12 \& 13)

Sports et divertissements, a delightful collection of twenty-one miniatures, is not only Satie's most ambitious piano work but arguably his finest creative achievement, a superb marriage of style and idea, a crystallization of virtually everything that had preceded it, the purest distillation of an aesthetic ideal toward which he had been groping for a quarter century.

Apparently the publishing house of Lucien Vogel had commissioned Stravinsky to compose a work to accompany an album of sketches by the illustrator Charles Martin depicting various sports and entertainments. Stravinsky, fresh from his recent succès de scandale with the Ballets Russes, refused on the grounds that the fee was too small. When similar terms were offered Satie, the beggarly composer is reported to have been insulted by what he considered too lavish an offer. Only when the publisher agreed to halve the fee did he settle down to compose a series of twenty miniatures, preceded by an "Unappetizing Chorale," which Vogel duly brought out in a deluxe limited edition that reproduced Satie's exquisite red and black notation along with Martin's drawings. In a Preface to the collection the composer explained his purpose:

This publication is made up of two artistic elements: drawing, music. The drawing part is represented by strokes-strokes of wit; the musical part is depicted by dots-black dots [i.e., blackheads]. These two parts together-in a single 
volume-form a whole: an album. I advise the reader to leaf through the pages of this book with a kindly and smiling finger, for it is a work of fantasy. No more should be read into it.

For the "Shriveled Up" and the "Stupified," I have written a serious and proper chorale. This chorale is a kind of bitter preamble, an austere and unfrivolous introduction.

I have put into it all I know of Boredom.

I dedicate this choral to those who do not like me.

I withdraw.

Once again Satie aimed his barbed wit at the scholasticism of the stuffy Academy. His tiny "Choral inappétissant" is to be played "hypocritically," in a "stern and surly" manner. So unappetizing is it, Satie tells us, that he composed it, on the morning of 15 May 1914, "on an empty stomach."

In his Preface the composer spoke of two artistic elements-drawing and music-modestly neglecting to mention a third, equally important, element, his inimitable verbal commentary, for each of the twenty miniatures, never more than four lines of music, is accompanied by a tiny poem in Satie's most delightful vein, surrealistic sketches which have been compared not without good reason to Japanese haiku:

\section{"The Hunt"}

Do you hear the rabbit singing?

What a voice!

The nightingale is in its burrow.

The owl is suckling her young.

The young wild boar is going to get married.

As for me, I'm knocking down nuts with rifle shots. 


\section{"The Sleigh"}

How cold it is!

Ladies, noses in your furs.

The sleigh flies along.

The landscape is very cold and doesn't know what to do with itself.

It should be obvious that an ideal performance of Sports et divertissements would involve a mere handful of aficionados gathered around a piano in intimate surroundings to delight simultaneously in the music, the poetry, and the artwork - itself a three-tier system comprising Martin's full-page aquarelles, Satie's calligraphic notation, and the small ink sketches that adorn each title page. ${ }^{7}$ As has been demonstrated, most of the "humoristic" piano pieces can be, and should be, approached as single musico-poetic entities with fairly obvious connections between quoted tunes and verbal commentary. In the Sports et divertissements the relationship between music and poetry, to which now is added a third element, drawing, is often quite subtle, even at times hermetic. But to perceive this fragile multi-dimensional texture is to savor the full flavor of these intriguing miniatures and experience them as the composer almost certainly intended.

7 There are five published versions of Sports et divertissements. In 1923 Lucien Vogel brought out a deluxe (and now rare) limited edition of 900 copies in two versions: 1) Nos. 1-225 include, with facsimiles of the music (black on red staves), all twenty of Martin's full-page copperplate engravings (colored by Jules Saudé), as well as small ink sketches decorating the title page of each piece; 2) the remaining 675 copies are identical except that they include only one full-page colored drawing as a frontispiece; 3) the 1964 Salabert edition, which retains the music in facsimile (minus the original red staves) and the black-and-white half-title pages preceding the individual pieces but eliminates Martin's aquarelles and reduces the size (15 7/16" x 17 $1 / 8$ " of the original by approximately half; 4) the 1975 Salabert edition in regular notation with English translations of Satie's texts by Virgil Thomson, but minus Martin's illustrations; 5) the 1982 Dover reprint of (1) also in smaller format (8 13/16" x 11 13/16") with black-and-white reproductions) and one color reproduction on the front cover) and English translations of Satie's texts, but minus the red staves and the half-title pages. 
In several of the pieces Satie indulges in a kind of Augenmusik wherein the musical score is an obvious graphic representation of the activity being depicted-the rocking accompanimental figure of "La Balançoire," for example, or the plunging scalar passage in the third line of "Le Water-Chute:"

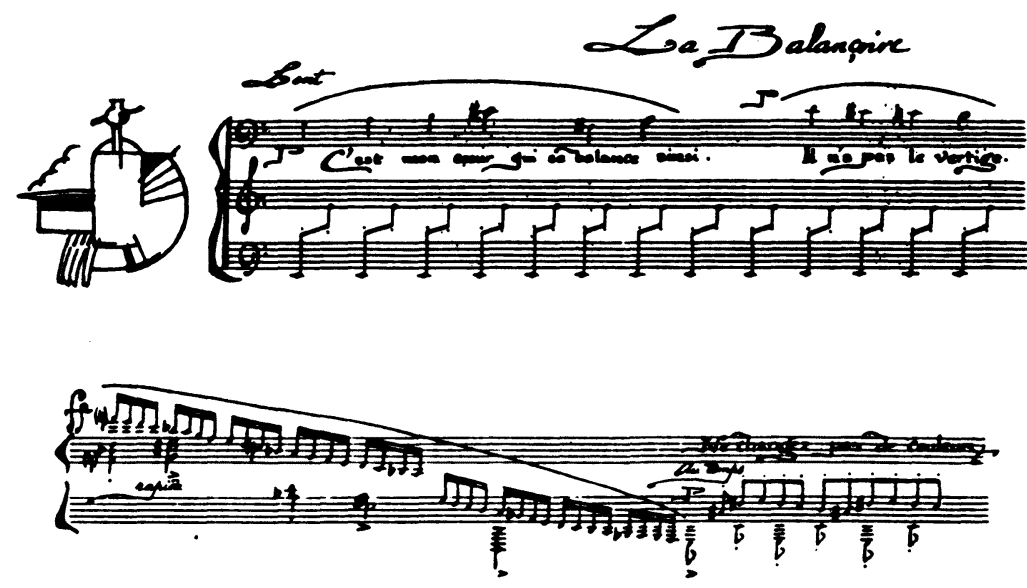

Figure 17. : Satie: Sports et divertissements (1914), "La Balançoire" (line 1) and "Le Water-Chute" (line 3)

Elsewhere the composer continues his practice of reflecting certain aspects of his verbal commentary in the music-the flourish of ascending fourths in "Le Golf," for example, as the Colonel's golf club flies to pieces, or, similarly, the ascending sweep of triplets ending in a bang, then a whimper, as the fireworks explode at the end of "Le Feu d'artifice:" 

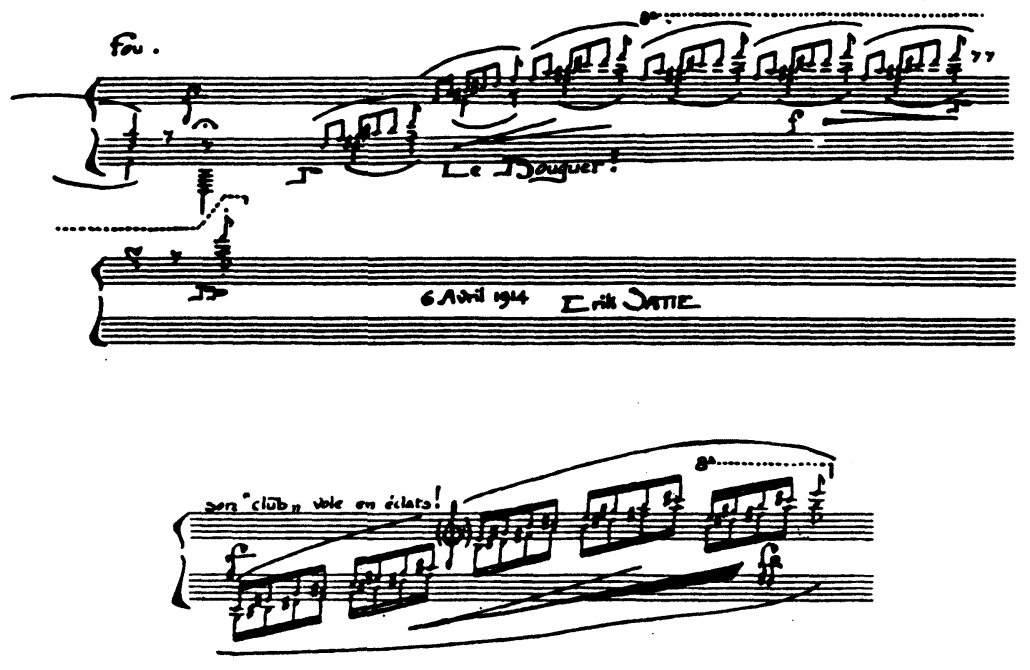

Figure 18. : Satie: Sports et divertissements (1914), "Le Golf" (line 4) and "Le Feu d'artifice" (lines 3-4)

Other musico-poetic correspondences are a little less obvious. "La Pêche," for example, opens with a soft ostinato pattern representing "the murmuring of the water in the riverbed." Soon a fish swims into view accompanied by a skittering bitonal flourish in the bass; seconds later the tiny figure is repeated. a ninth higher, as another fish swims by, followed by two concurrent flourishes in parallel fourths as two other fish momentarily appear. But the fish soon spot the angler and dart away home to the same flickering figures, their direction now reversed. The fisherman decides to pack it in and return home too, leaving only "the murmuring of the water in the riverbed," thus bringing to completion a perfect little arch form (A B C B A): 


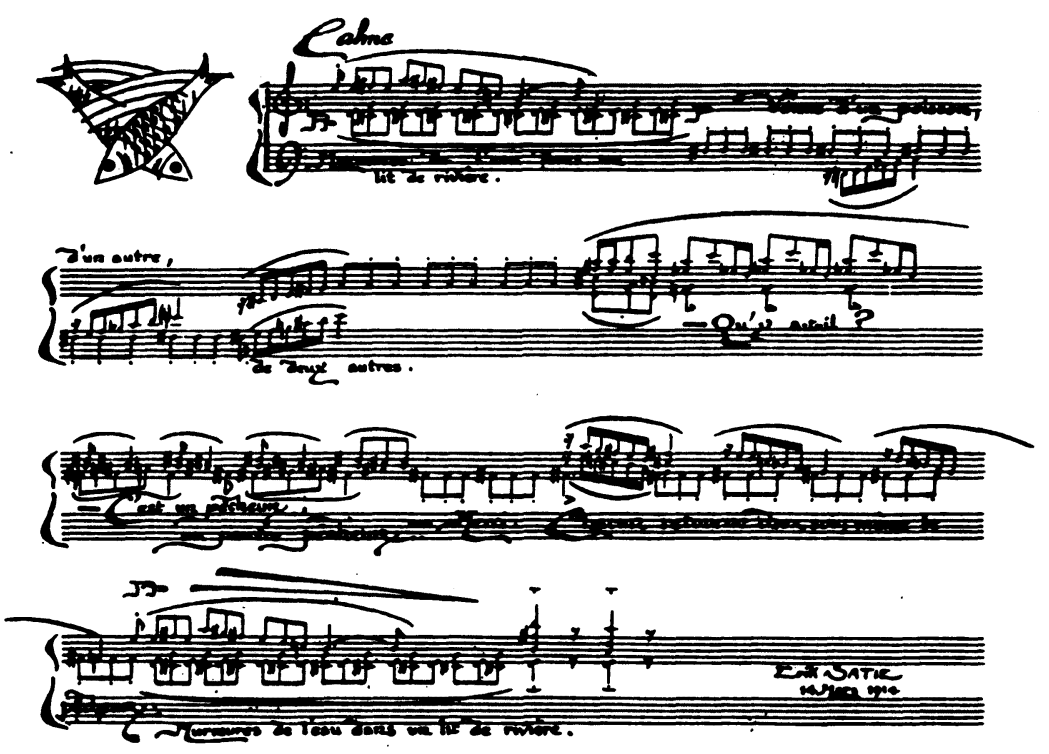

Figure 19. : Satie: Sports et divertissements (1914), "La Pêche"

The subtlest level of intertextural relationship in the Sports et divertissements involves correspondence between the musical and the visual elements. The sweeping arpeggios of "Le Bain de mer," for example, not only suggest (aurally and visually) the billowing waves of the ocean, the entire score itself is a graphic representation of the triangular drawing which accompanies it: 


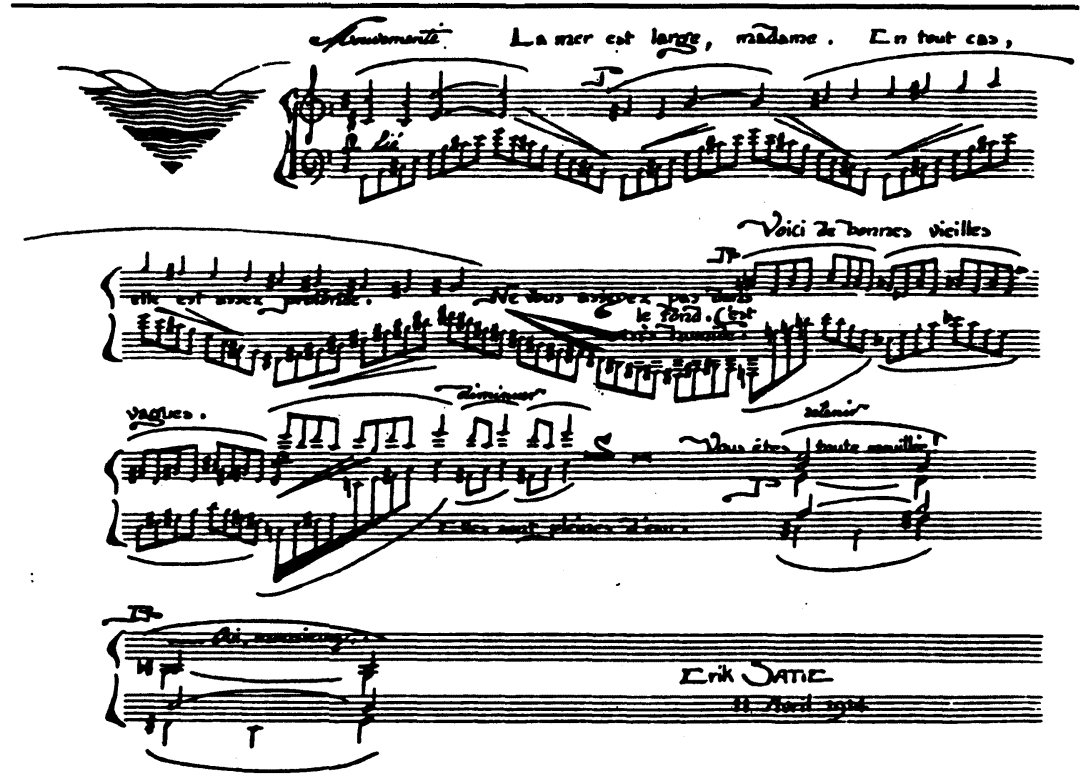

Figure 20. : Satie: Sports et divertissements (1914), "Le Bain de mer"

Although Sports et divertissements does not make copious use of quoted material, there are a few recognizable snatches of familiar melody. In "Le Reveil de la Mariée," for example, we hear a fortissimo version of the phrase "Dormez-vous, dormez-vous?" from "Frère Jacques" near the beginning of the piece where it serves as a wake-up call for the bride, followed by a strident distortion of "Reveille" as she is commanded to get up. In "Les Courses," a slightly distorted version of the famous opening phrase of "La Marseillaise" is heard at the end of the race where it serves as an ironic accompaniment to "The Losers (with pointed noses and drooping ears"), while in "Le Flirt" there is an unmistakable allusion to the well-known children's song "Au clair de la lune" which sounds near the end in response to the words, "Je voudrais être dans la lune." One final curiosity is the rather startling prefiguration of Vincent Youman's enormously popular "Tea for Two" from his 1923 musical No, No, Nannette at the beginning of "Le Golf." 
Sports et divertissements is sui generis, the one work in which the variegated strands of Satie's artistic experience are unselfconsciously woven into a single fragile tapestry of sight and sound-a precarious union of Satie the musician, the poet, and the calligrapher. Here in abundance is the epigrammatic wit, irony, and fantasy which, taken together, have come to mean Satiean. At turns droll and amusing, serious and sardonic, this tiny Gesamtkunstwerk affords us as meaningful a glimpse of the composer's subconscious dreamworld as we are ever likely to get.

The "humoristic" piano suites of 1913-14 share, for the most part, a common compositional modus operandi. The borrowed tunes are remarkably similar: conjunct and diatonic, with a melodic range rarely exceeding an octave. Most of them, as we have seem, belong to the repertoire of French children's songs and all of them had a wide currency at the time-as indeed most of them still do, even to some extent outside the francophone world. Moreover, Satie makes little or no attempt to disguise his sources, the tunes for the most part being quoted exactly or with very minor alterations. Indeed, the pieces rely upon a ready recognition of the borrowed material for their sly musico-poetic humor to be fully savored. ${ }^{8}$ Occasionally the humor takes the form of paradox - "The Orangutan Song," for example, counselling us not to fear the "hideous" stalk-eyed podolphthalma, or Rip's "It's a trifle, a puff of air, a trifle" accompanying the stone humper as he staggers under the "enormous" weight of his gigantic pumice stone; in other instances it depends upon outright parody, as in the inflated closing perorations of "Holothuria" and "Podolphthalma" suddenly intruding on the composer's bald two-part texture.

Typically a borrowed tune (or a characteristic fragment of one) is stated clearly at or very near the beginning of a piece. What follows is usually a series of repetitions of the tune (or tunes) with little or no melodic variation but in various harmonic contexts and at varying tonal levels.

8 Given the consistency of Satie's practice in this matter, the tendency of some writers to identify "influences" where the musical connections are rather tenuous is highly suspect; see, for example, Guichard (1973). 
The overall tonal framework of the pieces is usually defined either by a tonic/dominant or a tonic/tonic progression, although the final tonality is sometimes obscured through an unexpected twist in the cadence-the tone cluster at the end of "Le Porteur de grosses pierres," for example. Characteristically, short cells of music are juxtaposed, mosaic-like, in a seemingly haphazard fashion, negating any tendency toward a continuous narrative. Harmonies move about with abandon, the inherently tonal borrowed materials undermined by piquant and quirky harmonizations, often of a blatantly bitonal nature.

There is in this music - as in all of Satie's music - a curiously objective and unatmospheric quality. The composer does not use chords for their rhetorical or coloristic possibilities but rather he delights in the unexpected relationships he can discover between them. Through a concept of form free from motivic development, a formal idea arrived at through the juxtaposition of bits and pieces of commonplace materials, Satie disallows the rhetorical element that results from the dramatic accumulation of related musical events. The sensuous element, too, is negated through the extreme bareness of the texture and the mechanistic rigidity of the rhythmic impulse.

Clearly all of Satie's piano music from this period explores the mysterious world of the child, reminding us of one of the composer's most celebrated aphorisms: "When I was young, people used to say to me: Wait until you're fifty, you'll see. I am fifty. I haven't seen a thing" (Satie 1920). Because he never allowed the child in himself to surrender to the man, Satie had an uncanny ability to see children other than as diminutive adults. As Wilfrid Mellers has suggested, he "saw in childhood an ideal of emotional sincerity which he looked for in vain in the adult world around him" (Mellers 1942: 216). Also to the point is a perceptive comment by Satie's friend, the poet and critic René Chalupt, whose poem "Le Chapelier" he set to music in 1916. "The observation of the budding soul with an almost religious respect for its innocence, and the contemplation of its gradual awakening with a view of transforming it into artistic values," wrote Chalupt, "is an entirely modern inclination-possibly a sympton of decadence" (Chalupt 1919/20: 45). Certainly it seems that "children's music," as opposed to simple music for young pianists, is a relatively recent phenomenon, and, with the 
notable exceptions of Schumann and Mussorgsky, a peculiarly French preoccupation.

To be sure, one need not be a student of French history nor recognize the musical quotations in order to understand and appreciate Vieux sequins et vieilles cuirasses, Embryons desséchés, Chapitres tournés en tous sens, or any other of Satie's piano works of this period. Like any music of quality, these pieces can be enjoyed on a more or less abstract plane. All music, however, has a semiological aspect, and to be aware of the musico-poetic symbiosis operating in Satie's music is to be brought more completely into the composer's imaginative world. In this sense Satie's music - as much as Ives' - will remain encapsulated by time and geography, for the internal symbolism no longer has the same weighted emotional ambience it surely once had. 


\section{APPENDIX}

Quoted Tunes in Satie's "Humoristic" Piano Suites

Descriptions automatiques (1913)

1. "Sur un vaisseau"

2. "Sur une lanterne"

3. "Sur un casque"

"Maman, les p'tits bateaux" [No. 1]

"La Carmagnole" [No. 2]

Copyright 1913 by G. Schirmer Inc. on behalf of Editions Max Eschig. International Copyright Secured. All Rights Reserved. Used by permission.

Embryons desséchés (1913)

1. "d'Holothurie"

2. "d'Edriophthalma"

3. "de Podolphthalma"

Loïsa Puget: "Mon rocher de Saint-Malo" [No. 1]

Fryderyk Chopin: Sonata No. 2 in B-flat Minor for Piano, Op. 35 (1839), III. Marche funèbre, mm. 31-32 [No. 2]

Edmond Audran: "Chanson de l'Ourang-Outang" (refrain) from La Mascotte (1880), Act III [No. 3]

"Il était un' bergère" [No. 3]

Copyright 1913 by G. Schirmer Inc. on behalf of Editions Max Eschig. International Copyright Secured. All Rights Reserved. Used by permission. 
Croquis et agaceries d'un gros bonhomme en bois (1913)

1. "Tryolienne turque"

2. "Danse maigre (à la manière de ces messieurs)"

3. "Españaña"

Wolfgang Amadeus Mozart: Sonata in A Major for Piano, K. 331 (1778), III. Alla turca, mm. 25-32 [No. 1]

Emmanuel Chabrier: España (1883), mm. 61-64; 218-26 [No. 3]

Copyright 1913 by G. Schirmer Inc. on behalf of Editions Max Eschig. International Copyright Secured. All Rights Reserved. Used by permission.

Chapitres tournés en tous sens (1913)

1. "Celle qui parle trop"

2. "Le Porteur de grosses pierres"

3. "Regrets des Enfermés (Jonas et Latude)"

Aimé Maillart: "Ne parle pas, Rose, je t'en supplie!" (mm. 1-3) from Les Dragons de Villars (1856), Act I [No. 1]

Robert Planquette: “C'est un rien, un souffle, un rien" from Rip (1884), Act I, Finale, mm. 247-50 [No. 2]

"Nous n'irons plus au bois" [No. 3]

Copyright 1913 by G. Schirmer Inc. on behalf of Editions Max Eschig. International Copyright Secured. All Rights Reserved. Used by permission.

Vieux sequins et vieilles cuirasses (1913)

1. "Chez le marchand d'or (Venise XIIIe siècle)"

2. "Danse cuirassée (Période grecque)"

3. "Défaite des Cimbres (Cauchemar)" 
Charles Gounod: "Le veau d'or" (mm. 1-3) from Faust (1859), Act II [No. 1]

"La casquette du père Bugeaud" (derived from "Aux champs (en marchant)" [No. 2]

"Le bon roi Dagobert" [No. 3]

"Malbrough s'en va-t-en guerre" [No. 3]

Copyright 1913 by G. Schirmer Inc. on behalf of Editions Max Eschig. International Copyright Secured. All Rights Reserved. Used by permission.

Sports et divertissements (1914)

1. "Frère Jacques" in No. 5 ("Le Reveil de la Mariée")

2. "Reveille" in No. 5 ("Le Reveil de la Mariée")

3. "La Marseillaise" in No. 13 ("Les Courses")

4. "Au clair de la lune" in No. 19 ("Le Flirt")

Copyright 1914 by G. Schirmer Inc. on behalf of Editions Salabert. International Copyright Secured. All Rights Reserved. Used by permission. 


\section{REFERENCES}

CHALUPT, $\mathbf{R}$.

1919/20: "Children in Music." The Chesterian, I, 45-47; 72-75.

GUICHARD, L.

1973: "A propos d'Erik Satie: Notules incohérentes." Recherches et travaux (Université de Grenoble, Unité d'Enseignement et de Recherches des Lettres), Bulletin No. 7 (March), 63-80.

HYSPA, V.

1903: Chansons d'humour. Paris: Enoch.

JOUY, J.

1888: Les Chansons de l'année. Paris: Bourbier et Lamoureux.

\section{KLEIN, L.}

1966: "Twentieth Century Analysis: Essays in Miniature." Music Educators Journal, LIII, 25-26.

MELLERS, W.H.

1942: "Erik Satie and the 'Problem' of Contemporary Music." Music and Letters, XXIII, 210-27.

SATIE, E.

1920: Le Coq, No. 1 (May).

VAN VECHTEN, $C$.

1917: Interpreters and Interpretations. New York: Knopf.

VOLTA, 0.

1977: Erik Satie: Ecrits. Paris: Editions Champ Libre; rev. ed., 1981.

WECKERLIN, J.-B.

1884: Chansons de France pour les petits Français. Paris: Plon-Nourrit.

1885: Chansons et rondes enfantines. Paris: Garnier.

1886: Nouvelles chansons et rondes enfantines. Paris: Garnier.

1889: Chansons et rondes enfantines des provinces de la France. Paris: Garnier.

WIDOR, C.-M.

1883: Vieilles chansons et rondes pour les petits enfants. Paris: Plon-Nourrit.

WILKINS, $\mathbf{N}$.

1975: "The Writings of Erik Satie: Miscellaneous Fragments." Music and Letters, LVI, 288-307.

1980a: "Erik Satie's Letters to Milhaud and Others." Musical Quarterly, LXVI, 404-28. 
1980b: The Writings of Erik Satie. London: Eulenburg.

1981: "Erik Satie's Letters." Canadian University Music Review, No. 2, 207-27. XANROF, L.

1890: Chansons sans-gêne. Paris: Ondet. 